\title{
Bos Funds Allocation For Pilot Schools: Study On SDIT Bina Insan Qur'ani Cibatu-Garut
}

\author{
Ega Rahmat Pauzi \\ UIN Sunan Gunung Djati Bandung \\ egarahmatpauzi27@gmail.com \\ Imam Tabroni \\ STAI DR. KH. EZ. Muttaqien Purwakarta \\ imamtabroni70@gmail.com ${ }^{2}$
}

DOI: https://doi.org/10.52593/pdg.02.1.01

Naskah diterima: 21 Oktober 2020, direvisi: 14 Desember 2020, disetujui: 2 Januari 2021

\begin{abstract}
Educational actors are still confused in setting funding priorities for the development of pilot schools. This paper is intended to understand the priority allocation of pilot school funding originating from BOS funds. This research uses a qualitative method with an action research approach. The theory used is the concept of allocation and budgeting from Nanang Fattah. The problem that arises is what kind of financing sector gets more budgeting in pilot schools. From the findings in the field, it was found that the largest portion of the allocation of BOS funds for three years was in the funding of salaries for teachers and education staff. The budget design of SDIT Bina Insan Qur'ani uses a model of budgeting by line item. However, every year there is a change in the budgeting format. This was done to simplify school spending.
\end{abstract}

Keywords: Budgeting Allocation, BOS Funds, Pilot Schools.

\section{A. Introduction}

The government allows the community to establish schools in accordance with applicable regulations. At the very least, this can help expand educational opportunities without the need for government initiatives. The number of private schools is seen as a form of community spirit in educating the nation's children. So that the community, in this case education activists, is not passive in viewing various educational problems in Indonesia.

Unfortunately, the spirit of school establishment is not accompanied by the ability to create quality schools. In short, the increase in the number of schools was not followed by an increase in the quality of education (Abd Rahman: 7). Of course there are many factors behind this problem. However, if these symptoms are not avoided from the start, then improving the quality and quality of education at the school level will be increasingly difficult.

Among the aspects of school success is its ability to anticipate limited educational resources. Here the role and function of the principal as a manager is needed. 
Especially in the era of regional autonomy and school decentralization, the demand for self-sufficiency in school management has increased.

Given the limitations of school funding sources, a systematic effort is needed to make effective and efficient sources of these funds. One of the efforts is the best possible allocation and planning of education funding. Such efforts are very important especially for newly established schools. Successful management of school funding will greatly determine the learning process and even the future of schools.

This paper will explore budgeting priorities set by pilot schools. The aim is to understand what areas of need need more attention in the context of a new school. Funding needs between schools are certainly different, especially the needs of new schools compared to old schools.

\section{B. Literature Review}

According to Alan Thomas J, there are four types of budget that can be adopted, namely budgeting by line items, budgeting by organizational units, budgeting by functional categories and budgeting by programs or performance. The school that we discussed uses a type of budgeting by line item. According to Nanang Fattah, in budget item by item (budgeting by line item) each expenditure is grouped by categories (Nanang Fattah: 60). For example the needs of the learning process such as erasers, white boards, markers are put into one category.

Based on Ministry of Education Regulation No. 69 In 2009, the standard number of students in each class was 29 people. Despite the fact in the field the number of students is not always like that, especially in private schools. For superior schools, the charm of the quality of schools gave birth to the level of the queue of registrants for new students. The school is not worried about losing students.(Effendi, 2020) As for the pilot schools, achieving the target of new student admissions has become a special achievement especially if the school still relies on school funding from the School Operational Assistance.

The fact that BOS funds are determined by the number of students in each school greatly influences the student acceptance policy. Private schools compete for as many students as possible. Competition among schools raises the assumption that the quantity of education funding related to school quality depends on the ability of schools to attract new students. The impact of schools with a small number of students will experience quality stagnation and even a decline in the quality of education (Maman Rusmana: 163).

\section{Methodology and methods}

Action researchers start with the practical problems they face or someone in the community might face, this is about the allocation of BOS funds to pilot schools namely SDIT Bina Insan in Garut. The researcher helped find resources and information to overcome the problem of allocating BOS funds to pilot schools. The researcher was involved in collecting qualitative data with the headmaster, deputy

2 | Paedagogie: p-ISSN: 2337-6848, e-ISSN : 2723-5971 
principal, and staff who were directly related to BOS funds, as well as policy makers at the National Education Office. Researchers analyze data, often done collaboratively with participants, and develop and implement an action plan.

\section{Results and Discussion}

Integrated Islamic Elementary School (SDIT) Bina Insan Qur'ani (BIQ) was established in 2015. However this research will focus on school funding from 2016 to 2018. In 2016 SDIT BIQ already has two study groups (RomBel) with as many students 45 people, 2 class teachers, 1 Islamic teacher, 1 school operator, 1 cleaning staff and 1 treasurer. In RKAS 2016, SDIT BIQ received BOS funds from the central government of Rp. 36,000,000. The amount of funds is in accordance with the number of students multiplied by Rp. 800,000.

In 2017 SDIT BIQ received BOS funds from the central government in the amount of Rp. 48,000,000. The funds count is based on the number of students and the funds per student. That year SDIT BIQ had 60 students with three study groups (RomBel).

Whereas in 2018, SDIT BIQ received central BOS funds of Rp. 113,600,000. From the 2018 RKAS data, the author found a different BOS fund allocation format compared to the previous two years. There is a simplification in the category of distribution of BOS funds. School spending is only divided into three, namely personnel expenditure, goods and services expenditure, and capital expenditure.

The BOS funds are then allocated to finance various school operational needs. The following data is about the allocation of BOS SDIT BIQ funds in 2016 as a percentag.

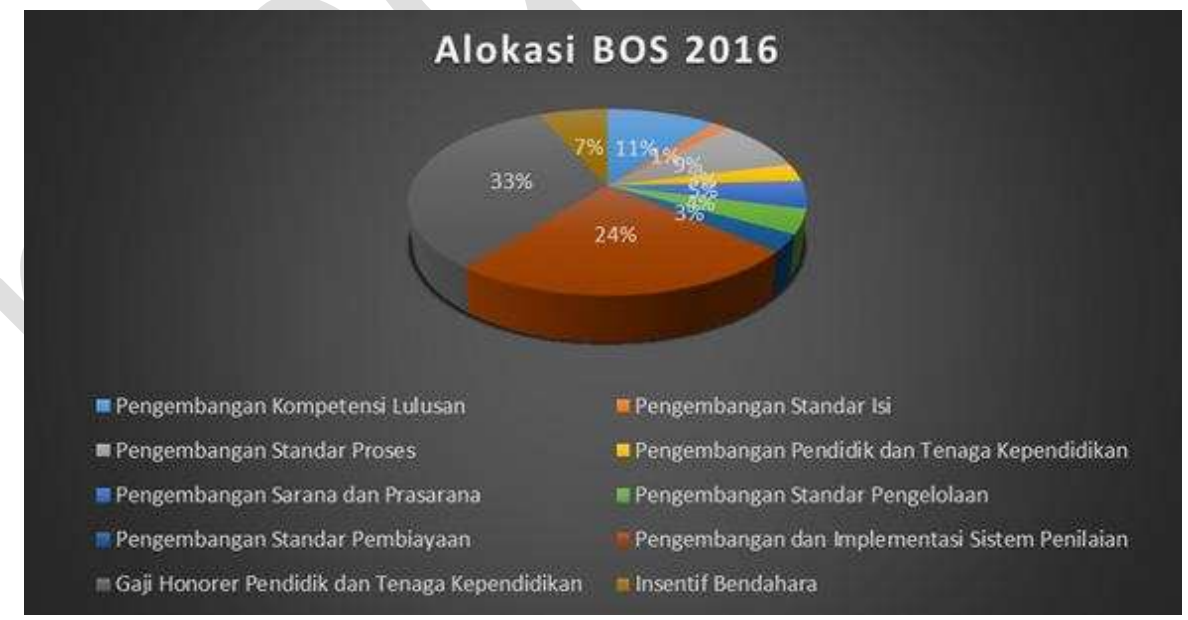

Diagram 1. Based on RKAS SDIT Bina Insan Qur'ani 2016.

The allocation of BOS 2016 funds is spread into ten needs. The first eight needs are aimed at developing eight elements which are included in the eight national standards. The other two are channeled to pay salaries and incentives for educators and education personnel. 
The diagram above it appears that the largest amount of funding for BOS funds is the payment of salaries and incentives for temporary teachers, treasurers and education personnel. This proves that even though the status is private, schools still rely on BOS funds to pay their employees. Such dependence is reasonable when looking at the condition of schools that have not been established in terms of finding other sources of funding.

The second largest allocation is financing the development and implementation of an appraisal system. The details are $56 \%$ of the funds to finance the assessment in the form of daily tests, midterm tests and end of semester tests. While $15 \%$ of the funds are for innovation evaluation models which consist of workshops, training and comparative studies.

In 2017, a description of expenditure in the school activity plan and budget (RKAS) removed the salary column for teachers and honorary staff and treasurer incentives. Disbursement of honorariums lies under the development of financing standards. So that the allocation for development of financing standards is inflated. Another expense that has been inflated is the development of process standards. Below I summarize the BOS 2017 allocation data in a diagram.

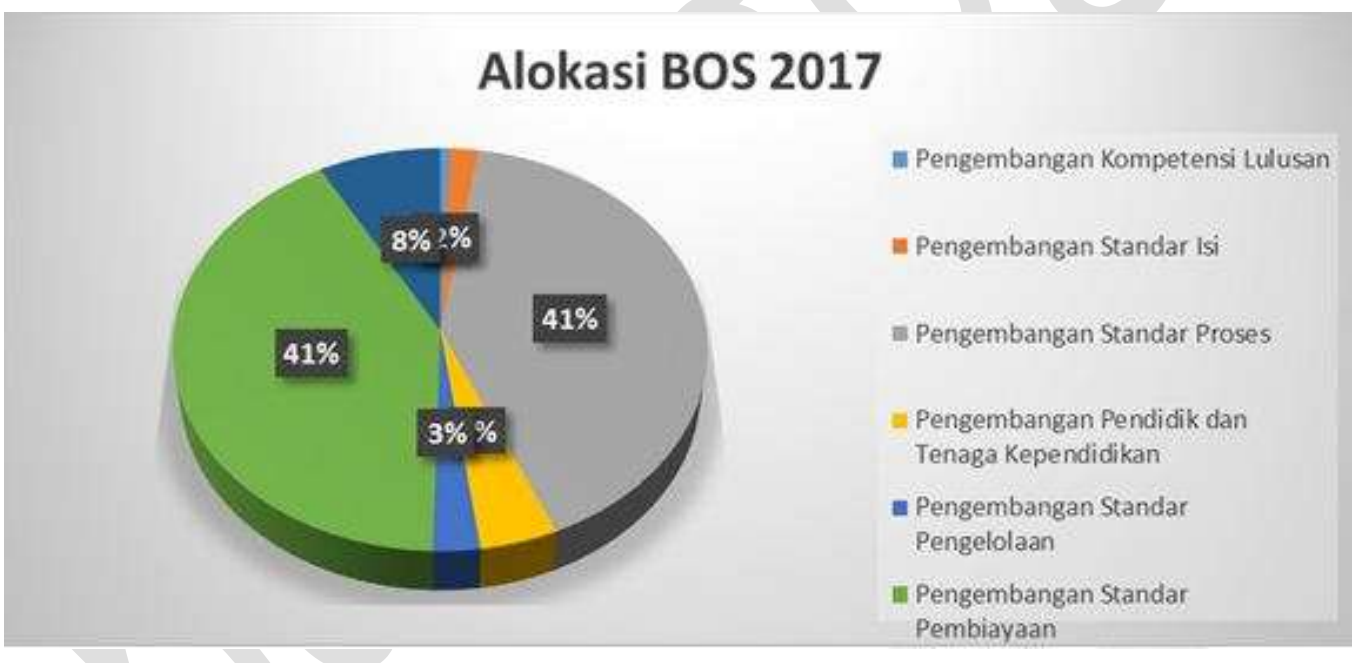

Diagram 2. Based on the RKAS SDIT Bina Insan Qur'ani 2017.

It appears that the allocation of standard development processes and development of financing standards is equal to $41 \%$. Interestingly, there was a very significant decrease in the allocation of development and implementation of the assessment system.

The dynamics of the allocation of funds is therefore caused by several factors. Regarding the reduction in the allocation of development and implementation of the appraisal system, the authors found expenditure efficiencies in several places such as the elimination of funding for the preparation of the grid, follow-up assessments, and the creation of other tasks. Even the integration of questioning and assessment 
implementation in one category further simplifies the amount of development funding and the appraisal system.

The main reason for the increase in the allocation of funding standard development is the placement of various salary and honorarium payments in that standard. It was noted that $81 \%$ of the standard funding allocation was spent on paying teacher salaries.

Another need that absorbs BOS members is the development of process standards. The increase in the allocation of standard development processes was due to the efforts of schools in providing various learning resources. It is calculated that $82 \%$ of funds for the development of standard processes are spent on the provision of learning resources. Of this amount, as much as $59 \%$ is aimed at procuring library books. It is seen here that school policies prioritize funding sources for learning support needs that can be used long-term.

The format of the 2018 school activity plan and budget is simpler. There are only three categories created, namely personnel expenditure, goods and services expenditure, and capital expenditure. Capital expenditure consists of capital expenditure for machine tools, capital expenditure for other fixed assets, and capital expenditure for buildings and buildings. Even so, capital expenditure financing is only used for capital expenditure of other fixed assets.

\section{Alokasi BOS 2018}

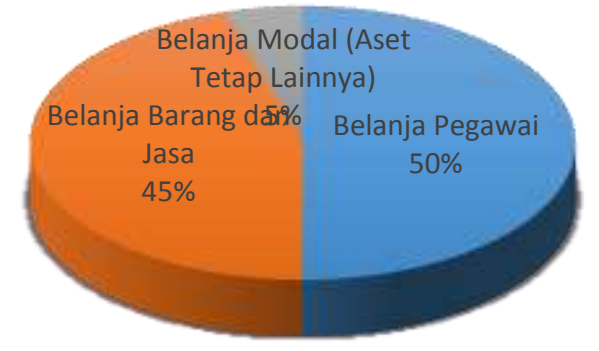

ש Belanja Pegawai Belanja Barang dan Jasa $\quad$ Belanja Modal (Aset Tetap Lainnya)

\section{Diagram 3. Based on the RKAS SDIT Bina Insan Qur'ani 2018.}

The largest portion of BOS funds is still intended to pay salaries for educators and education staff. Payment of teacher salaries consumed $40 \%$ of the total BOS funds. The distribution of BOS fund allocations in goods and services spending is spread evenly. This means that there is no inflation of funds in one particular sector. Capital expenditure for fixed assets in the form of providing learning support facilities with the largest allocation is in the purchase of printers, teacher desks, and the procurement of students' basic textbooks. 


\section{E. Conclusion and Funding}

In the midst of all the limitations experienced by the new school management, the provision of BOS funds breathed fresh air for the development of the school. But managers must pay close attention to determining the amount of the budget for each school's needs. Mismanagement in the management of BOS funds will not only harm the government as a funder but also the future of the school. Weaknesses in managing BOS funds can shorten school age especially for newly established schools.

The Bina Insan Qur'ani Integrated Islamic Elementary School (SDIT BIQ) which was established in 2015 until now has received BOS funds for three years in a row. The financial sector that has absorbed BOS members for three years is the payment of employee salaries. Even so the school is trying to allocate BOS funds for long-term interests such as holding various training (2016), procurement of various learning resources (2017), and providing learning support facilities.

\section{References}

Ghani, Abd Rahman A. (2014). Metodologi Penelitian Tindakan Sekolah, Jakarta: Rajagrafindo Persada.

Fattah, Nanang. (2017). Manajemen Pembiayaan Pendidikan Berbasis Aktivitas Pembelajaran, Bandung: Rosdakarya.

Effendi, M. R. (2020). Mitigasi Intoleransi dan Radikalisme Beragama di Pondok Pesantren Melalui Pendekatan Pembelajaran Inklusif. Paedagogie, I(I), 55-74. https://doi.org/doi.org/10.20211/pdg.01.1.05

Effendi, M. R. (2020). Mitigasi Intoleransi dan Radikalisme Beragama di Pondok Pesantren Melalui Pendekatan Pembelajaran Inklusif. Paedagogie| Jurnal Pendidikan dan Studi Islam, 1(1), 56-75.

Rusmana, Maman dan Hamdani, Agus. (2015). Penentuan Anggaran BOS Berdasarkan Jumlah Siswa terhadap Pelayanan Pembelajaran yang Berkeadilan di Sekolah Dasar. Jurnal Ilmu Pendidikan 21, 160-166.

RKAS 2016-2018 SDIT Bina Insan Qur'ani Cibatu Garut. 